\title{
Epidemiological aspects of Toxoplasma gondii infection in riverside communities in the Southern Brazilian Amazon
}

\author{
Sérgio Neto Vitaliano ${ }^{[1],[2]}$, Gabriel Maciel de Mendonça ${ }^{[3]}$, Felipe Amsterdam Maia de Sandres ${ }^{[3]}$, \\ Juliana de Souza Almeida Aranha Camargo ${ }^{[3]}$, Paulo de Tarso ${ }^{[3]}$, Sérgio de Almeida Basano ${ }^{[3],[4],}$ \\ Jéssica Carolinne Damasceno e Silva ${ }^{[3]}$, Viviane Krominski Graça de Souza ${ }^{[3]}$, \\ Glenci Cartonilho ${ }^{[5]}$, Alexandre Thomé da Silva de Almeida ${ }^{[3]}$, Solange Maria Gennari ${ }^{[2]}$ \\ and Luís Marcelo Aranha Camargo ${ }^{[3],[6]}$
}

[1]. Curso de Medicina Veterinária, Faculdades Metropolitanas Unidas, São Paulo, São Paulo, Brasil. [2]. Faculdade de Medicina Veterinária e Zootecnia, Universidade de São Paulo, São Paulo, São Paulo, Brasil. [3]. Faculdade São Lucas, Porto Velho, Rondônia, Brasil. [4]. Secretaria de Estado da Saúde de Rondônia, Hospital Cemetron, Porto Velho, Rondônia, Brasil. [5]. Laboratório Central de Saúde Pública, Secretaria Municipal de Saúde de Porto Velho, Porto Velho, Rondônia, Brasil. [6]. ICB5/USP - Unidade Avançada de Pesquisa, Universidade de São Paulo em Rondônia, Monte Negro, Rondônia, Brasil.

\begin{abstract}
Introduction: Toxoplasma gondii infection is widely prevalent in humans and other animals worldwide. Information on the prevalence of $T$. gondii infection is scarce in some regions of Brazil, including riverside communities along the Amazon River basin. Methods: The prevalence of T. gondii in 231 people, aged 1-85 years, who were living in four riverside communities along the Purus River, Lábrea, State of Amazonas, Brazil, was determined. Antibodies against $T$. gondii were assayed using a commercial enzyme-linked immunosorbent assay (ELISA) kit. The hearts and brains of 50 chickens, which were raised freerange in the communities, were pooled according to the community of origin and bioassayed in mice. The isolates were genotyped using polymorphisms at 12 nuclear markers (SAG1, 5' and 3'-SAG2, alt.SAG2, SAG3, BTUB, GRA6, c22-8, c29-2, L358, PK1, Apico and CS3). Results: The overall seroprevalence of $T$. gondii was 56.7\% (131/231). IgG antibodies were presented by $117(89.3 \%)$ and IgM by $14(10.7 \%)$ of the 131 positive individuals. No association between age group and gender with prevalence was observed (chi-square test, $\mathrm{p}>0.05$ ); however, the comparison between localities showed that the seroprevalence of $T$. gondii was significantly lower among the individuals living in the Boca do Ituxi $(\mathrm{p}<0.05)$ community. Five isolates of T. gondii were obtained in the mouse bioassay, and genotyping revealed two complete genotypes that had not been described previously and three mixed isolates. Conclusions: These results support previous findings that $T$. gondii population genetics are highly diverse in Brazil and that $T$. gondii infection is active in these riverside communities.
\end{abstract}

Keywords: Toxoplasma gondii. Riverside communities. Amazon. Purus River. Epidemiology.

\section{INTRODUCTION}

Toxoplasma gondii infection is widely prevalent in humans and other animals worldwide ${ }^{(1)}$. In Brazil, the burden of clinical toxoplasmosis in humans is considered to be very high, as up to $50 \%$ of elementary school children and $50-80 \%$ of women of childbearing age show antibodies against $T$. gondii ${ }^{(2)}$. Despite the large number of studies that have investigated the epidemiology of this agent in human beings and animals, information on

Corresponding author: Dra. Solange Maria Gennari. Depto. de Medicina Veterinária Preventiva e Saúde Animal/FMVZ/USP. Av. Professor Orlando M. de Paiva 87, Cidade Universitária, 05508-270 São Paulo, Brasil.

Phone: 5511 3091-7654; Fax: 5511 3091-7928

e-mail: sgennari@usp.br

Received 6 February 2015

Accepted 24 April 2015 the prevalence of $T$. gondii infection is scarce in some regions of Brazil. As a result, it is difficult to establish the distribution of the agent and to implement control measures in these regions.

The Brazilian Amazon region is geographically, socially and ecologically different from other parts of the world, yet there are few studies on $T$. gondii in this region. Cavalcante et al. ${ }^{(3)(4)}$ found a prevalence of $73.3 \%$ in humans, $87.3 \%$ in cats and $37.5 \%$ in pigs on 71 farms in the municipality of Monte Negro, Rondônia, in the western Amazon region. From the same area, T. gondii was isolated in free-range chickens and, based on restriction fragment length polymorphism (RFLP), 24 isolates were genotyped $^{(5)}$, and seven different genotypes were found ${ }^{(6)}$, thus confirming the high diversity of $T$. gondii isolates in Brazil(7) (8). Furthermore, the pathogenicity of Brazilian strains, based on mouse bioassays, suggested that they carry a higher virulence than isolates from other regions of the world ${ }^{(7)}$.

In the Amazon region of French Guiana, from 1998 to 2006, 44 cases of severe toxoplasmosis, caused by an atypical isolate, 
were observed in immunocompetent adults ${ }^{(9)}$. Mercier et al. ${ }^{(10)}$, also in French Guiana, compared T. gondii isolates originating from anthropized suburban areas and from the wild environment and observed that the two environmental populations, wild and anthropized, were genetically well differentiated.

The aim of the current study was to determine the prevalence of $T$. gondii in humans living in riverside communities in the Amazon region of Brazil and to biologically and genetically characterize the T. gondii isolates from chickens that were raised in the same communities using 12 polymerase chain reaction-restriction fragment length polymorphism (PCR-RFLP) markers.

\section{METHODS}

\section{Human and animal ethics}

This study was approved by the Research Ethics Committee of São Lucas College, Porto Velho, Rondônia (protocol number $\mathrm{AP} / \mathrm{CEP} / 538 / 10$ 06/12/2010). The use of animals was in accordance with the Ethical Principles for Animal Research adopted by the Brazilian College of Animal Experimentation.

After processing the serological data and identifying the positive patients, the team returned to the communities, and the patients underwent medical examinations.

\section{Location and sampling}

The municipality of Lábrea $\left(07^{\circ} 15^{\prime} 34^{\prime \prime} \mathrm{S}\right.$ and $\left.64^{\circ} 47^{\prime} 59^{\prime \prime} \mathrm{W}\right)$, located in the State of Amazonas, Brazil, has a population of approximately 38,000 inhabitants, of whom 5,000 live in 112 riverside communities along the Purus River. From these 112 communities, four were chosen for convenience in the present study: Boca do Ituxi, with a population of approximately 80 inhabitants $\left(07^{\circ} 18^{\prime} 40.3^{\prime \prime} \mathrm{S} ; 64^{\circ} 50^{\prime} 52.2^{\prime \prime} \mathrm{W}\right)$; Maciari, with approximately 100 inhabitants $\left(07^{\circ} 16^{\prime} 56^{\prime \prime} \mathrm{S}\right.$; $\left.64^{\circ} 51^{\prime} 03.5^{\prime \prime} \mathrm{W}\right)$; Cassianã, with approximately 80 people $\left(07^{\circ} 17^{\prime} 27.3^{\prime \prime} \mathrm{S} ; 64^{\circ} 55^{\prime} 19.2^{\prime \prime} \mathrm{W}\right)$; and Bosque, with 90 people $\left(07^{\circ} 16^{\prime} 53.1^{\prime \prime} \mathrm{S}\right.$; $\left.64^{\circ} 51^{\prime} 0.56^{\prime \prime} \mathrm{W}\right)$. These communities are located to the West of Lábrea, towards the Purus headwaters, $50 \mathrm{~km}$ away from the center of the municipality.

By making the assumption that the seroprevalence of T. gondii would be $30 \%$ and using a margin of statistical error of less than 5\%, the minimum sample from the total population was estimated to be 60 individuals.

Blood samples were collected from 231 individuals aged 1-85 years and living in 67 households. A signed consent form was obtained from all the adults and from the parents or legal guardians of the minors who participated in this survey. Serum was obtained, identified and stored at $-20^{\circ} \mathrm{C}$ prior to analysis.

Fifty chickens living in the areas around the human dwellings were acquired by means of random collection: 15 from Cassianã, 15 from Maciari, 15 from Boca do Ituxi and 5 from the Bosque community. The animals were sacrificed, and the brain and heart of each bird were harvested aseptically, identified, kept refrigerated $\left(4^{\circ} \mathrm{C}\right)$ and sent, by air, to the Faculty of Veterinary Medicine of the University of São Paulo, in São Paulo, for the isolation of $T$. gondii by means of a mouse bioassay.
During the visits to each home, a questionnaire was administered. The independent variables studied included the presence of cats, meat consumption, hunted meat consumption, drinking water origin, water storage, presence of filtered water, water treatment and, for the women older than 15 years, reproductive problems.

\section{Diagnosis of anti-Toxoplasma gondii antibodies in serum}

The human serum samples were sent to the Central Laboratory of Public Health [Laboratório Central de Saúde Pública (LACEN)], located in the City of Porto Velho, Rondônia, for the determination of immunoglobulin $\mathrm{M}$ (IgM) and immunoglobulin $\mathrm{G}$ (IgG) antibodies by means of enzyme-linked immunosorbent assay (ELISA), using the TSI-TOXOK-M ${ }^{\circledR}$ commercial kit (DiaSorin, Saluggia, Italy) according to the manufacturer's recommendations.

\section{Mouse bioassay}

For the mouse bioassay, the chickens were divided into groups, with five birds per group, according to the community of origin. The chickens from Cassianã, Maciari and Boca do Ituxi were pooled into three groups each, and those from Bosque were pooled into one group. The tissue fragments from the five chickens (brain and heart) were pooled together, homogenized, digested in acidic pepsin and washed. Aliquots of the homogenates were inoculated subcutaneously into five outbred Swiss Webster mice. Tissue imprints of the lungs and brains of the inoculated mice that died were examined for T. gondii tachyzoites or tissue cysts. The survivors were bled on day 45 post-infection, and a 1:25 dilution of the serum was tested for $T$. gondii antibodies by means of the modified agglutination test (MAT), as described by Dubey and Desmonts ${ }^{(11)}$. The mice were sacrificed on day 60 post-infection, and the brains of all the mice were examined for tissue cysts. The inoculated mice were considered to have become infected by $T$. gondii when tachyzoites or tissue cysts were found in their tissues.

\section{Genetic characterization of the Toxoplasma gondii isolates}

Toxoplasma gondii deoxyribonucleic acid (DNA) was extracted from the lungs and brains of infected mice. Strain typing was performed using the genetic markers SAG1, 5 ' and 3'-SAG2, alt.SAG2, SAG3, BTUB, GRA6, c22-8, c29-2, L358, PK1, Apico and CS3, as described previously ${ }^{(7)}(12)$. Reference strains, including Type I (RH), Type II (PTG) and Type III (CTG), and other strains ( $\mathrm{TgCgCa} 1 \mathrm{MAS}$ and $\mathrm{TgCatBr} 5$ ) were used in the genotyping assays as positive controls.

\section{Statistical analyses}

Associations between gender, age group and locality were determined by means of the chi-square test using $\mathrm{R}$ software (R Core Team, 2014). The level of significance was fixed at 0.05 .

\section{RESULTS}

Cats, dogs, chickens, ducks and pigs were present in all the communities. Chickens, ducks and pigs were used for human consumption, and cats were present in $43 \%$ of the residences, 
all with free access to the external area. River water was used for drinking and food preparation by all of the families that answered the questionnaire ( 8 out of the 67 families did not answer this question). Only $15 \%$ of the families used chlorine in the drinking water; however, its use depended on the distribution by the local health board, which only occurred at irregular intervals. It was not possible to analyze some of the variables, including the presence of cats, meat consumption, hunted meat consumption and drinking water source, because all the communities that were analyzed presented the same profile. Only gender, age and location of the samples were statistically analyzed.

Table 1 presents the seroprevalence of $T$. gondii in humans, according to age group, community and gender.

Out of the total of 67 homes, 19 (28.3\%) were in Cassianã, $23(34.3 \%)$ in Maciari, 13 (19.4\%) in Boca do Ituxi, and $12(18 \%)$ in Bosque. Of the 360 total inhabitants, 231 (64.1\%) were present and consented to sample collection. These individuals comprised 118 (51\%) males and 113 (49\%) females. The ages of the sampled individuals ranged from 1 to 85 years, and approximately $43 \%$ of the subjects were children.

The overall seroprevalence of anti- $T$. gondii antibodies was $56.7 \%(131 / 231)$. Among the positive individuals, 14 (10.7\%) presented IgM antibodies and 117 (89.3\%) presented $\mathrm{IgG}$ antibodies.

No associations between age group, gender and prevalence were observed $(p>0.05)$. However, the comparisons between localities showed that there was a significantly lower $T$. gondii seroprevalence among those living in Boca do Ituxi $(p=0.0002)$.
Of the total of 113 females examined, 62 (55\%) were of childbearing age (12-44 years), and 19 (30.6\%) reported having suffered a spontaneous miscarriage during the 12-month period before the study. Among these 19 women, seven (36.8\%) presented IgG antibodies against $T$. gondii, and they lived in the communities of Cassianã (4), Boca do Ituxi (1) and Bosque (2).

Table 2 presents the results from the mouse bioassays for isolating T. gondii from the chicken tissues, and Table 3 presents the genotyping of the $T$. gondii isolates. Five isolates were obtained by means of the mouse bioassay from the chickens from Boca do Ituxi (2) and Cassianã (3); however, the complete genotype was only obtained from two isolates from Boca do Ituxi; the other three isolates were mixed genotypes. All of the infected mice died during the bioassay, at times ranging from day 15 to 26 post-infection.

\section{DIsCUSSION}

This study evaluated riverside communities along the Purus River in the Amazon River basin that represent a typical population with the peculiar characteristics and habits of the inhabitants of the riverside areas of the Amazon region.

The individuals examined had been living in their communities for at least five years. The rainfall characteristics of this region force these individuals, for at least four months a year, to have close day-to-day contact (in the household and peri-domestic areas) with their synanthropic animals. Moreover, the consumption of chicken, duck and pig meat during

TABLE 1 - The prevalence of anti-Toxoplasma gondii IgM and IgG antibodies in humans (n=231) in the riverside communities, according to the age group, community and gender. Lábrea, State of Amazonas, Brazil.

\begin{tabular}{|c|c|c|c|c|c|c|}
\hline \multirow[b]{2}{*}{ Age group (years) } & \multicolumn{3}{|c|}{ Samples examined } & \multirow{2}{*}{$\begin{array}{c}\text { Total } \\
\text { prevalence } \\
\%\end{array}$} & \multirow[b]{2}{*}{$95 \% \mathrm{CI}$} & \multirow[b]{2}{*}{$X^{2}(p)$} \\
\hline & total & $\%$ & $\begin{array}{c}\text { positive } \\
\operatorname{IgM} / \operatorname{IgG} \text { (total) }\end{array}$ & & & \\
\hline $15-29$ & 60 & 26.0 & $3 / 34(37)$ & 61.7 & $49.0-72.9$ & \\
\hline $30-44$ & 37 & 16.0 & $2 / 24(26)$ & 70.3 & $54.2-82.5$ & \\
\hline$>60$ & 19 & 8.2 & $0 / 12(12)$ & 63.1 & $41.0-80.8$ & \\
\hline \multicolumn{7}{|l|}{ Community } \\
\hline Cassianã & 54 & 23.4 & $2 / 31(33)$ & 61.1 & $27.6-50.6$ & $19.46(<0.01)$ \\
\hline Maciari & 52 & 22.5 & $2 / 25(27)$ & 52.0 & $36.9-63.1$ & \\
\hline \multicolumn{7}{|l|}{ Gender } \\
\hline male & 118 & 51.1 & $6 / 59(65)$ & 55.1 & $46.1-64.1$ & $0.142(0.706)$ \\
\hline female & 113 & 49.0 & $8 / 58(66)$ & 58.4 & $49.3-67.4$ & \\
\hline
\end{tabular}

IgM: immunoglobulin M; IgG: immunoglobulin G; CI: confidence interval. 
TABLE 2 - The results from the mouse bioassays using pooled chicken tissue (brain and heart), according to the community from which the birds originated. Lábrea, State of Amazonas, Brazil.

\begin{tabular}{lccccc}
\hline & \multirow{2}{*}{$\begin{array}{c}\text { Number of } \\
\text { chickens/number } \\
\text { of pools* }\end{array}$} & inoculated & infected & death (\%) & day of death + (No. of mice) \\
\cline { 3 - 6 } Cassianã & $15 / 3$ & 15 & 15 & $15(100.0)$ & $15(1), 16(1), 17(1), 18(2), 19(3), 20(2), 21(2), 22(3)$ \\
Maciari & $15 / 3$ & 15 & 0 & $0(0.0)$ & $15(4), 16(1), 17(1), 19(1), 26(1)$ \\
Boca do Ituxi & $15 / 3$ & 15 & $8 \dagger$ & $8(100.0)$ & $0(0.0)$ \\
Bosque & $5 / 1$ & 5 & 0 & $23(100.0)$ & \\
\hline Total & $50 / 10$ & 50 & 23 & 23 of mice & \\
\hline
\end{tabular}

*pooled tissue from five chickens per group of five mice; $\uparrow:$ positive mice from two of the three pools; $;$ : days after the inoculation.

TABLE 3 - Multilocus genotyping of Toxoplasma gondii isolates from free-range chickens from Boca do Ituxi, a riverside community along the Purus River, municipality of Lábrea, State of Amazonas, Brazil, by means of PCR-RFLP analysis.

\begin{tabular}{|c|c|c|c|c|c|c|c|c|c|c|c|c|c|}
\hline Sample ID & \multicolumn{12}{|c|}{ PCR-RFLP genotype } & $\begin{array}{c}\text { ToxoDB } \\
\text { PCR-RFLP genotype }\end{array}$ \\
\hline TgCkBr282 & I & I & I & I & III & III & I & III & III & $\mathrm{u}-1$ & I & $\mathrm{u}-1$ & $\# 257^{*}$ \\
\hline TgCkBr283 & I & I & II & I & I & III & II & III & I & III & I & NA & $\# 258^{*}$ \\
\hline
\end{tabular}

PCR-RFLP: polymerase chain reaction-restriction fragment length polymorphism; ID: Identification; ToxoDB: Toxoplasma gondii genome database (http://www.toxodb.org/toxo); NA: not available, \#: number; *first described in the present study.

this season is the main source of animal protein because fishing is more difficult during the rainy season.

In all the dwellings surveyed, there was at least one domestic animal, and $43.2 \%$ were cats, which serve as the definitive host of $T$. gondii. The majority of these animals had contact with each other and also with humans, especially during the rainy season. Wild felids are also present nearby these communities, and they may also be involved in the wild life cycle of $T$. gondii ${ }^{(13)(14)}$.

One important feature of these communities was the large number of young people in this population: $42.9 \%$ were children (1-14 years old), and 42\% were between 15 and 44 years, i.e., of reproductive age. Among the children, 46.5\% (46 out of 99) would reach childbearing age having already had contact with this parasite. Among the total of 14 IgM-positive individuals, nine $(64.3 \%)$ ranged in age from 1-14 years, indicating that contact with this parasite occurs early in life. Consistent with this high prevalence, $30.4 \%$ (19) of the women who had been pregnant in the previous six months reported having suffered a spontaneous miscarriage without any defined cause, and seven of them presented IgG antibodies against the parasite, thus indicating that T. gondii might have been involved in the abortion.

In these communities, there was a lack of medical and prenatal care. Because of the high prevalence and low level of knowledge regarding the epidemiology of this parasite, vertical transmission can certainly be presumed to occur. In particular, the high rate of IgM-positive individuals, associated with the high number of women of childbearing age, serves to alert the authorities to the need to improve the prenatal program in these communities, given that $T$. gondii infection is active in these locations.

The overall prevalence of anti- $T$. gondii antibodies found in this study was $55.7 \%$, and this percentage is within the range found in other Brazilian regions and in the Amazon region ${ }^{(2)}$. However, the present study was the first to be conducted among riverside communities, which present peculiar habits related to the environment. For instance, the system of flood and drought that is seen in the Purus River most likely dilutes the environmental contamination by oocysts and therefore the exposure of the inhabitants. Recently, toxoplasmosis has acquired special importance as a waterborne disease ${ }^{(13)}$. Moreover, the parasite has also been reported in marine mammals, thus suggesting that the infection can occur through the contamination of seawater with oocysts. Important aquatic mammals (Trichechus inunguis) are also found in the Amazon basin, and they have been found to be T. gondii-seropositive ${ }^{(15)}$. Although the studied animals were from captivity, the high prevalence of $T$. gondii infection found in the riverside populations as well as chickens from these communities indicates that contamination of the rivers with oocysts can be presumed to occur.

These communities are in close contact with areas of forest, and wild animals are likely to come into contact with the peridomiciliary environment; thus, this interaction may favor the contamination of wildlife by oocysts that are eliminated by the cats living in the communities. However, there is also the possibility that wild felines, infected by $T$. gondii, contaminate areas of the peri-home. 
Despite the lack of an association observed between age and the presence of $T$. gondii antibodies, an increasing prevalence rate with age was observed; whereas the children (1 to 14 years old) presented a rate of $46.5 \%$, the adults showed a prevalence rate of more than $60 \%$. This higher prevalence with increasing age is associated with a greater chance of acquiring infection due to increased exposure to the various transmission factors over time. It is difficult to explain the lowest prevalence observed in Boca do Ituxi because the living conditions were very similar in all the communities analyzed. However, it should be noted that this locality is the closest of the four communities to the urban area of Lábrea, which may indicate that this area has different sources of food and a better quality of water provided by the local health system.

Corroborating the data obtained in this study, previous studies have shown a relationship between $T$. gondii infection and socioeconomic factors ${ }^{(16)(17)}$, with higher socioeconomic status correlated with a lower $T$. gondii seroprevalence. The relatively high prevalence found in the present study is consistent with the results of previous studies and is related to the low socioeconomic status of the communities evaluated here.

According to Dubey et al. ${ }^{(5)}$, domestic chickens are a good indicator of environmental contamination with $T$. gondii oocysts, such that they are used as sentinel animals in many studies around the world. In the present study, the results obtained for chickens provide information on the state of environmental contamination and warn about the care that must be taken in preparing the meat of such animals for human consumption. All riverines raise chickens and other domestic animals, such as pigs and ducks, for consumption, especially during the rainy season when fishing is more difficult.

All the chickens included in this study were used for the mouse bioassays, regardless of knowledge of the birds' serostatus. Out of the ten pools, five presented positive animals, and all the infected mice died. However, although all the isolates were virulent and lethal to the infected mice, conclusions regarding the virulence of these isolates cannot be made without knowing the dosage of the inoculum ${ }^{(18)}$. Nevertheless, the pathogenic profile observed here is indicative of a high virulence, as observed with the majority of Brazilian isolates ${ }^{(2)(8)}$.

Complete genetic characterization was successful in only two isolates from birds living in the same community. These isolates showed distinct and atypical genotypes, and neither has been described previously. Although $T$. gondii infection is asymptomatic in most immunocompetent hosts, severe cases of toxoplasmosis caused by atypical genotypes have been described in the Amazon region of French Guiana ${ }^{(19)(20)(21)}$.

Another interesting observation in our study was the presence of mixed genotypes in three pools of chicken tissue from the same community, indicating a very high genetic diversity in the localities studied. Nevertheless, additional chickens from these communities should be bioassayed to provide more details about the genetic diversity of $T$. gondii in this important region. However, the use of pooled tissue is not recommended because of the distinct genotypes of $T$. gondii found in the same small geographical area.

\section{ACKNOWLEDGMENTS}

We thank Mr. Oscar Brito, the boat pilot; Dr. Raimundo Nonato, who is in charge of the local health system; and the riverside communities of Lábrea. We also thank the Research Foundation of the State of São Paulo [Fundação de Amparo à Pesquisa do Estado de São Paulo (FAPESP)], Brazil, for financial support. SMG and LMAC received scholarships from the Brazilian National Research Council [Conselho Nacional de Desenvolvimento Científico e Tecnológico (CNPq)].

\section{CONFLICT OF INTEREST}

The authors declare that there is no conflict of interest.

\section{REFERENCES}

1. Dubey JP. Toxoplasmosis of Animals and Humans. $2^{\text {nd }}$. ed. Boca Raton: CRC Press; 2010.

2. Dubey JP, Lago EG, Gennari SM, Su C, Jones JL. Toxoplasmosis in humans and animals in Brazil: high prevalence, high burden of disease, and epidemiology. Parasitol 2012; 139:1375-1424.

3. Cavalcante GT, Aguiar DM, Camargo LMA, Labruna MB, de Andrade HF, Meireles LR, et al. Seroprevalence of Toxoplasma gondii Antibodies in Humans From Rural Western Amazon, Brazil. J Parasitol 2006a; 92:647-649.

4. Cavalcante GT, Aguiar DM, Chiebao D, Dubey JP, Ruiz VLA, Dias RA, et al. Seroprevalence of Toxoplasma gondii Antibodies in Cats and Pigs from Rural Western Amazon, Brazil. J Parasitol 2006b; 92:863-864.

5. Dubey JP, Gennari SM, Labruna MB, Camargo LMA, Vianna MCB, Marcet PL. Characterization of Toxoplasma gondii isolates in free-range chickens from Amazon, Brazil. J Parasitol 2006; 92:36-40.

6. Dubey JP, Velmurugan GV, Chockalingam A, Pena HFJ, Oliveira LN, Leifer CA, et al. Genetic diversity of Toxoplasma gondii isolates from chickens from Brazil. Vet Parasitol 2008; 157: 299-305.

7. Pena HFJ, Gennari SM, Dubey JP, Su C. Population structure and mouse-virulence of Toxoplasma gondii in Brazil. Int J Parasitol 2006; 38:561-569.

8. Shwab EK, Zhu XQ, Majumdar D, Pena HFJ, Gennari SM, Dubey JP, et al. Geographical patterns of Toxoplasma gondii genetic diversity revealed by multilocus PCR-RFLP genotyping. Parasitol 2014; 141:453-461.

9. Carme B, Demar M, Ajzenberg D, Dardé ML. Severe acquired toxoplasmosis caused by wild cycle of Toxoplasma gondii, French Guiana. Emerg Infect Dis 2009; 15:656-658.

10. Mercier A, Ajzenberg D, Devillard S, Demar MP, de Thoisy B, Bonnabau H, et al. Human impact on genetic diversity of Toxoplasma gondii: example of the antropized environment from French Guiana. Inf Gen Evol 2011; 11:1378-1387.

11. Dubey JP, Desmonts G. Serological responses of equids fed Toxoplasma gondii oocysts. Equine Vet J 1987; 19:337-339.

12. Su C, Shwab EK, Zhou P, Zhu XQ, Dubey JP. Moving towards an integrated approach to molecular detection and identification of Toxoplasma gondii. Parasitol 2010; 137:1-11. 
13. Jones JL, Dubey JP. Waterborne toxoplasmosis - Recent developments. Exp Parasitol 2010; 124:10-25.

14. Cañón-Franco WA, Araújo FA, López-Orozco N, Jardim MM, Keid LB, Dalla-Rosa C, et al. Toxoplasma gondii in free-ranging wild small felids from Brazil: Molecular detection and genotypic characterization. Vet Parasitol 2013; 197:462-469.

15. Mathews PD, Silva VMF, Rosas FCW, d'Affonseca Neto JA, Lazzarini SM, Ribeiro DC, et al. Occurrence of antibodies to Toxoplasma gondii and Leptospira spp in Manatees (Trichechus inunguis) of the Brazilian Amazon. J Zoo Wild Med 2012; 43:85-88.

16. Bahia-Oliveira LMG, Jones JL, Azevedo-Silva J, Alves CCF, Oréfice F, Addiss DG. Highly endemic, waterborne toxoplasmosis in north Rio de Janeiro State, Brazil. Emer Inf Dis 2003; 9:55-62.

17. Garcia CAA, Oréfice F, Lyra CO, Gomes AB, França M, Garcia Filho CCA. Socioeconomic conditions as determining factor in the prevalence of systemic and ocular toxoplasmosis in Northeastern Brazil. Ophthal Epid 2004; 11:301-317.

18. Vitaliano SN, Soares HS, Minervino AHH, Santos ALQ, Werther $\mathrm{K}$, Marvulo MFV, et al. Genetic characterization of Toxoplasma gondii from Brazilian wildlife revealed abundant new genotypes. Int J Parasitol: Paras Wild 2014; 3:276-283.

19. Ajzenberg D, Bañuls AL, Su C, Dumètre A, Demar M, Carme B, et al. Genetic diversity, clonality and sexuality in Toxoplasma gondii. Int J Parasitol 2004; 34:1185-1196.

20. Carme B, Bissuel F, Ajzenberg D, Bouyne R, Aznar C, Demar M, et al. Severe acquired toxoplasmosis in immunocompetent adult patients in French Guiana. J Clin Microb 2002; 40:4037-4044.

21. Wendte JM, Gibson AK, Grigg ME. Population genetics of Toxoplasma gondii: New perspectives from parasite genotypes in wildlife. Vet Parasitol 2011; 182:96-111. 